\title{
A Feasibility Study of Improving College Students' Critical Thinking Skills Through English Public Speaking
}

\author{
Jie Bao \\ Tianjin University of Finance and Economics \\ Tianjin, China
}

\begin{abstract}
Critical thinking skills are embedded in students' competence of making public speeches in English. This study tries to investigate the effect of English speech training on developing students' critical thinking by using content analysis and interviews. Participants in an English public speaking training program were interviewed twice during the program and their speech drafts were analyzed. The result of the study shows the improvement of students' critical thinking skills and the feasibility of introducing speech training into college English class.
\end{abstract}

Keywords-critical thinking skills; English public speaking training; college English teaching

\section{INTRODUCTION}

\section{A. Critical Thinking}

Critical thinking refers to the objective analysis of facts to form a judgment. It is embodied in a person's ability to perceive, analyze, understand, evaluate and settle a certain issue. There are abundant studies of critical thinking skills in western countries and the ability to think critically has been listed as one of the educational objectives for schools of tertiary level since the 1990s. In China, based on the theoretical frameworks of western studies, scholars have adapted and proposed new models and theories of critical thinking. For example, Lin [1] proposed the three-edged model of thinking in 2006. Wen [2,3] proposed a framework to evaluate students' critical thinking skills in 2009 and tested the validity and reliability of the framework in a later study in 2010. The framework Wen proposed is consisted of higher level skills and lower level skills. Meta-critical skills on the higher level govern the critical thinking skills on the lower level which includes cognitive and affective component. Analyzing skills, reasoning ability and evaluation ability were all considered to be cognitive skills. The framework also clarified the standards which these cognitive skills are supposed to meet. Affective component, on the other hand, refers to typical emotional attributes like curiosity, open-mindedness, confidence, integrity and perseverance. This framework has become a powerful theoretical framework for studies of college students' critical thinking skills.

\section{B. Critical Thinking and English Education in China}

There have been dates among scholars over the critical thinking skills of learners of English at tertiary level. Huang [4] first put forward the concept of "critical thinking absence" of college English majors in 1998. He pointed out that learners of English were often speechless when they had to present their ideas or argue for something. This absence of critical thinking skills had hindered the development of their language competence. Followed this paper, Huang [5] further investigated the problem in 2010 and still held the view that even after 11 years, learners of English were still "absent" in terms of critical thinking skills. On the other hand, Ren [6] rebutted the argument of "critical thinking absence" by an empirical study and proposed that Chinese college students' critical thinking ability is not weaker than western counterparts and language majors' critical thinking ability is not weaker than students of other liberal arts majors either. She also stressed the importance of integrating critical thinking into foreign language teaching syllabus. This echoes the argument of Sun [7], in which he claimed that developing critical thinking is the core objective of college education.

\section{Critical Thinking and English Public Speaking}

Compared with daily communication, English public speaking is a more advanced form of communication with higher requirement for the speakers' critical thinking skills. It's quite challengeable for the speakers to perform or deliver a speech to a live audience. In public speaking activities, students are not only required to be proficient and fluent, but also are expected to have logic in their speeches. They have to choose their topic, analyze the existing facts and opinions and propose their argument with logical reasoning. The whole process of analyzing, reasoning, and evaluating embodies the cognitive skills illustrated in Wen's framework of critical thinking. Besides, curiosity is developed when speakers try to find their topics and search for available materials; confidence is built when speakers try to deliver their speeches to the audience; courage is exercised when speakers try to get rid of the stage freight. These all agrees with the emotional attributes mentioned in Wen's critical thinking framework. On the other hand, English public speaking training is more than presenting the speakers own ideas, it also involves listening and understanding other 
speakers' speeches, identifying the reasons as well as loopholes in their speeches. The critical listening involved is also beneficial to the development of the speakers' critical thinking skills [8]. In conclusion, the training of English public speaking will undoubtedly help the speakers to develop their communicative competence and more importantly, critical thinking skills. [9][10]

Though studies have proved the importance of English public speaking in developing students' critical thinking and recognized the importance of critical thinking in college English education, public speaking courses have not yet been popularized in college English courses, especially in college English courses for non-English majors. Yet in recent years, English public speaking contests have been thriving among university students in China and more and more universities begin to provide pre-contest trainings for the candidate students. Few studies have provided empirical evidence toward the effect of these trainings on students' language competence and critical thinking. This paper, through a case study of the pre-contest training of one of the most prestigious English speaking contests - the FLTRP Cup, tries to investigate the effect of English public speaking training on developing students' critical thinking skills and explore the possible ways of integrating this kind of training in college English courses.

\section{RESEARCH DESIGN}

\section{A. Participants}

The participants of the study included 7 undergraduate students from Tianjin University of Finance and Economics. All the 7 participants were recruited to an English public speaking training program for the 2017 "FLTRP Cup" speech contest in Tianjin. Among these 7 participants, 3 are English majors and the rest are non-English majors. 3 out the 7 participants have taken part in the same contest last year. The English proficiency of the 7 participants was marked by CET (College English Test), which is considered to be of high validity and reliability among English proficiency tests in China. "Table I" that shows the basic information of the 7 participants.

TABLE I. BASIC INFORMATION OF THE PARTICIPANTS

\begin{tabular}{|l|l|l|l|l|l|l|l|}
\hline & \multicolumn{1}{|c|}{ A } & \multicolumn{1}{c|}{ B } & \multicolumn{1}{c|}{ C } & \multicolumn{1}{c|}{ D } & \multicolumn{1}{c|}{ E } & \multicolumn{1}{|c|}{ 作 } \\
\hline Gender & Male & Female & Female & Female & Female & Female & Female \\
\hline Major & English & English & English & $\begin{array}{l}\text { Non- } \\
\text { English }\end{array}$ & $\begin{array}{l}\text { Non- } \\
\text { English }\end{array}$ & $\begin{array}{l}\text { Non- } \\
\text { English }\end{array}$ & $\begin{array}{l}\text { Non- } \\
\text { English }\end{array}$ \\
\hline $\begin{array}{l}\text { English } \\
\text { Proficiency }\end{array}$ & CET6 & CET6 & CET6 & CET6 & CET6 & CET6 & CET6 \\
\hline $\begin{array}{l}\text { Contest } \\
\text { experience }\end{array}$ & Yes & Yes & No & No & Yes & No & No \\
\hline
\end{tabular}

\section{B. Research Questions}

The study aims to answer the following 2 questions:

- Has the training of English public speaking improved students' critical thinking skills?

- In what ways has the training program influenced students' critical thinking?

\section{Research Methods and Instruments}

The author held a training program for the 7 contest candidate three months before the contest. Candidate students were gathered together 3 times a week to be trained in both prepared and impromptu speeches. The author observed the whole training process and made notes for every training sections. Students were asked to hand in their drafts of prepared speeches and the author analyzed the contents of their drafts. Feedbacks were given to the students for their further revision and this process went on till the students finished their final drafts of their prepared speeches. Besides, topics of impromptu speeches were given by the author through wechat group twice a week. Students were asked to send voice messages in the wechat group to finish the impromptu speeches. After every student had finished his or her speech, the teachers would give comments on the students' performance and students were also required to do peer review. The voice messages were transcribed and analyzed by the author. The author also conducted semi- structured interviews with the 7 students to get more information about their perceptions of the training program, the forming process of their speech drafts and the change of their thinking patterns during the whole process.

\section{FINDINGS AND DISCUSSIONS}

\section{A. The Phenomenon of "Critical Thinking Absence" Is Still Prevailing Among Candidate Students}

By analyzing the content of students' speech drafts, the author found that quite a few students were illogical when illustrating their point of view. The argumentations they made were shallow and lack of sound evidence. Some of the students wrote a lot of slogans in their speech drafts without any concrete examples and appropriate reasoning. The lack of critical thinking skills has actually hindered the students from making in-depth communication with the audience through their speeches.

In the students' interview, nearly all the students admitted that language is not the only reason that makes public speaking challenging, the real tough thing for them to do is to perceive the topic critically, logically organize their thoughts, form their own arguments and collect appropriate data and facts to support their own argument. In this whole painstaking process, critical thinking skills are especially important for the speakers. 
"I always pay attention to one-side of the story when I'm asked present my views on a certain topic and when I looked back at my earlier drafts of my speech, I realized for the first time that how many overgeneralizations I have made." (Student Interview, D)

"As an English major, I'm actually pretty confident at my vocabulary and grammatical knowledge. But when I come across a speech topic, I always had no idea about what to say even in Chinese." (Student Interview, B)

Such findings agree with the statements of many Chinese scholars when they commented on the critical thinking skills of Chinese students. That's probably because of the fact that traditionally, Chinese education pays much attention to the factual knowledge and students at a very young age were required to memorize rather than to think. Students were always trapped in the conventional thinking and gradually lost their interest and ability in critical thinking.

\section{B. Intensive Training of Public speaking Can Arouse Students' Awareness of Mental Practice}

Students are faced with a multitude of impromptu speech topics in every training session. In order to have a good performance to increase their odds of earning a spot in the municipal contest and save themselves from awkward silence in every training session, all the candidate students began to pay more attention to the content knowledge of sociology, history and philosophy. They gradually formed habits of reading newspapers and magazines to broaden their horizons and at the same time, they began to read, listen and think critically. By analyzing the transcribed voice messages of students' impromptu speeches, the author found the dramatic changes of students' thinking patterns. Their onesided, subjective and superficial views were replaced by arguments supported by logical reasoning from multiperspectives.

For example, when asked about their opinions on planted advertising in China's Spring Festival Gala, student A first showed total aversion to the phenomenon because planted advertising ruined his mood. Gradually, he learned to analyze and evaluate the phenomenon from multi-angles such as market requirement, economic benefit, and promotion of domestic brands and so on.

In the students' interview, students also recognized the improving of their critical thinking skills through the training of English public speaking.

"The speech training program has roused my interest in thinking. I began to pay attention to hot news and I formed the habit of reflecting on the news or social phenomenon as well as making remarks on them." (Student Interview, F)

"Through the training program, I grew deeper understanding of many concepts and ideas. For example, I used to have biased and stereotyped views on the definition of feminism, but now I've got a deeper and broader understanding through discussing it with the teacher and fellow candidates in the training program and searching for materials after the training sessions." (Student Interview, A)
"Because of the pre-contest training program, I now know how to collect data and how to exact useful information in the vast amount of data. I also became better at clarifying my argument and justifying it with relevant evidence." (Student Interview, G)

The cultivation of students' critical thinking skills may be a long-term process, yet delightful changes have taken place through the English public speaking training program. Students begin to have the awareness of independent thinking. They are jumping out of their comfort zone of established ideas and begin to view and evaluate things from multi-angles.

\section{Public Speaking Training Can Help Students to Develop Critical Listening}

Public speaking is a two-way or even multi-way communication. In the training program, no matter face-toface or via wechat group, the students were all asked to give comments and feedback to other students' speeches. Students are not only viewed as candidates but are also viewed as judges in the training program. According to the field notes made at every face-to-face training session and the analysis of the transcribed voice messages in wechat group, the author found that at the earlier stage of the training program, the most commonly used expressions by the students when making comments fell into 2 categories: compliment and agreement, as can be seen in "Table II"

TABLE II. HIGH-FREQUENCY EXPRESSIONS OF MAKING COMMENTS

\begin{tabular}{|l|l|}
\hline \multicolumn{1}{|c|}{ Compliment } & \multicolumn{1}{|c|}{ Agreement } \\
\hline $\begin{array}{l}\text { "I think you have made a very good } \\
\text { point." }\end{array}$ & $\begin{array}{l}\text { "I totally agree with you." } \\
\text { "I have nothing to add." } \\
\text { "It's very inspiring." }\end{array}$ \\
\hline
\end{tabular}

But gradually, with the increase of their content knowledge and the improvement of their thinking ability, students began to listen critically. They learned to evaluate and question the sayings of their fellow candidates. And they became very active in finding their candidates' loopholes in the speeches.

"Instead of listening and parroting other people's ideas, now I always hold critical views towards when I listen to other people talk. I learn to analyze and evaluate their ideas and relate their ideas to my own perceptions."

By critical listening, students build a bridge between their existing knowledge and other people's knowledge and perceptions. By identifying the essence as well as the loopholes in other people's knowledge and perceptions, students gradually improve their own cognition of the outside world. Besides, by critically commenting on other people's idea, students build their courage and confidence and become more open-minded. This conforms to the emotional attributes in Wen's framework. 


\section{Pre-contest Public Speaking Training Program Is Helpful but Lacks Sustainable Effect}

Of the 7 student participants in this study, 3 students also took part in the pre-contest training program in 2016 and 2 of them have competed in the municipal contest in 2016. 9 months after the municipal contest in 2016, the 3 students were again chosen to join the pre-contest training program of 2017. At the beginning of the program, English public speaking teachers and experts were invited by the author to evaluate all the 9 candidates in the group. It is found that the 3 experienced candidates did a better job at speech delivering, but were still inadequate in terms of speech organization. For example, Student E tried to cover too many aspects in her speech and failed to dig deeper in every perspective. Student $\mathrm{B}$ piled up a lot of data, testimony and examples without logically organizing them. On the whole, all the three experienced candidates showed no significant progress compared with last competition season. In the interview, the 3 students reflected on their performance since last year.

"Since the last competition season ended, I have been relaxing myself because the training has also ended. There's no chance for me to speak out my views on certain issues without the training community." (Student B)

"Having gone through the intensive training of last year's program, I was at my best in last year's municipal contest. But after the contest, my language proficiency as well as thinking ability had all been dropping. Compared with the new candidates in this year's training program, the only thing I was better at was my pronunciation and my speech delivering skills. Without the training program, I was less motivated to read materials critically and train my thinking ability. I now know all the tips for English public speaking, but what I'm lack of are content knowledge and thinking ability." (Student E)

Wen \& Zhou [11] pointed out that students are more dependent on memorizing, imitating and reciting when they learn languages so that their thinking ability has been constrained to a certain degree. Short-term English public speaking training has opened a door for them to learn to thinking critically, but how to build a long term effective mechanism to encourage critical thinking is still a challenging job.

\section{CONCLUSION}

Through a case study of the pre-contest training program of English public speaking, this paper investigates the effect of public speaking training on students' development of critical thinking skills. The result shows that English public speaking training can effectively help students to raise their awareness of independent thinking and improve their critical thinking skills in the short term. The study has provided more empirical evidence for the role of English public speaking activities in developing students' thinking ability and raising students' confidence and awareness of communication. [12]

The study also finds that despite its effective role in developing students' critical thinking skills, English public speaking training program also has its limits in terms of scope and time. It would be a worthwhile attempt to effectively integrate this training model with college English courses, which have larger audiences and more class hours. Further effort should be made to find effective ways of integrating this model to the current college English curriculum.

\section{REFERENCES}

[1] Chongde Lin, Review of Studies of Thinking Psychology, J. Journal of Beijing Normal University (Social Science). 5(2006) 35-42

[2] Qiufang Wen, et. al, Constructing the Critical Thinking Framework for Language Majors in China, J. Foreign Language World. 1(2009) $37-43$

[3] Qiufang Wen, et. al, Revision and Reliability/Validity Test of the Critical Thinking Framework for Language Majors in China, J. Foreign Language World. 4(2010) 19-26

[4] Yuanshen Huang, Absence of Critical Thinking, J. Foreign Language and Foreign Language Teaching. 7(1998) 19

[5] Yuanshen Huang, Revisiting the "Absence of Critical Thinking": Reforms of Curriculum for English Majors, J. Foreign Language World. 1(2010) 11-16

[6] Wen Ren, Revisiting Foreign Language Majors' Critical Thinking Skills - A Case Study of English Public Speaking Course, J. Foreign Languages in China. 1(2013) 10-17

[7] Youzhong Sun, Highlighting the Cultivation of Critical Thinking and Deepening the Curriculum Reform of English Majors, J. Foreign Languages in China. 3(2011) 49-58

[8] Lucas, Stephen E. The Art of Public Speaking (10th ed) , McGraw Hill, New York, 2008

[9] Wen Ren, English Public Speech Teaching and Development of Comprehensive Abilities, J. Foreign Languages in China. 6 (2007) 66-70

[10] Zhang, D. Y, Public Speaking and the Development of Language Competence. In L. Wang, \& P. Li (Eds.), English Public Speaking in Global Context: Challenges and Innovations (pp. 125-133). Foreign Language Teaching and Research Press, Beijing, 2009

[11] Qiufang Wen, Yan Zhou, A Review of the Development of Critical Thinking of Language Majors, J. Foreign Languages Research. 5(2006) 76-80

[12] Explorations of Public Speaking Courses: New Oral Course for English Majors, J. Foreign Language World. 3(2001) 46-52 